DJSA (2017) 11, 1-23

DOI:http://dx.doi.org/11.3126/dsaj.v11i0.18820

\title{
Significant Heritages of Upper Mustang and Issue of Conservation
}

\author{
Prakash Darnal
}

\begin{abstract}
Upper Mustang has been an important centre of Tibetan Buddhism for many centuries. The walled city of Lomanthang with three monasteries Jyampa, Thubchen and Chodye, Chortens and mani wall, the monasteries of Namgyal, Loghekar, Charang, Ghami and Ghiling, the palaces of Lomanthang and Charang, the Chungsi, Gonga Gang and Luri caves, the 305-metre long Mani wall and Khorok chortens in Ghami, and the group of chörtens in Tangya are the outstanding tangible monuments of Upper Mustang, which are collectively significant because of their paintings, sculptures, manuscripts and other artefacts, and also because of their intangible heritage. Upper Lo Mustang is famous for its hundreds of caves. It's famous river Kaligandaki, is the only river in Nepal where śāligrāmas, stones containing ammonites, are found. These black stones are very sacred to both Buddhists and Hindus. Upper Mustang is the most promising area in Nepal for archaeological work. It is rich in both indigenous biodiversity and cultural heritage. The main purpose of this article is to light on how important is the Mustang in aspect of archaeological and heritages, it also focus on how new built road would impact its heritages.
\end{abstract}

Keywords: Archaeological caves, petroglyph, heritages, saligram (Ammonite), anthropomorphic figure 


\section{Introduction}

Lo-manthang is the main Buddhist cultural hub of Upper Mustang, situated between $28^{\circ} 36 \mathrm{~N}$ and $29^{\circ} 19^{\prime} \mathrm{N}$ and between $83^{\circ} 28^{\prime} \mathrm{E}$ and $84^{\circ} 8^{\prime} \mathrm{E}$ in North-Western Nepal at an altitude of 3,781 $\mathrm{m}$. The name used most commonly outside the region itself is Mustang, a deviant pronunciation of Manthang. It is called Lo after its inhabitants, the Lobas. Surrounded by Tibet on three sides and bounded by snowcapped mountains in the east and west, it is shielded from rainfall, and so has an arid climate. Consequently it has very little arable land, most of the soil being composed of a loose conglomerate of rounded pebbles and sand. Agriculture, animal husbandry and trade have been the main sources of livelihood in Lo since ancient times, but now tourism is also becoming a major component of the local economy. Upper Mustang is the most promising area in Nepal for archaeological work. It is rich in both indigenous biodiversity and cultural heritage. Organic samples found in cave system have revealed that the cave settlement in the Muktinath valley may go back beyond 4000 BC (Schuh, 1992, p. 93).

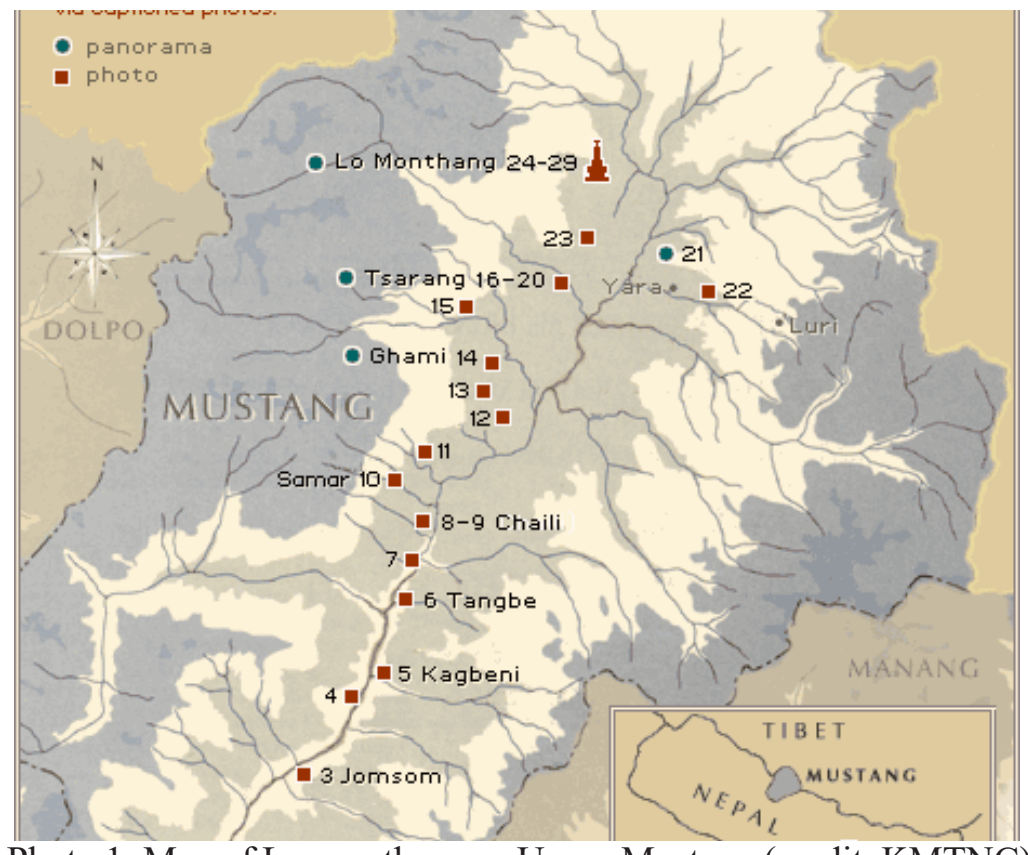

Photo 1: Map of Lo-manthang or Upper Mustang (credit, KMTNC) 
Lo-manthang's early history is bound up with the western province of Ngari in Tibet. The region is mentioned in the chronicles of Ladakh from the time of Srong btsans gampo in the $7^{\text {th }}$ century. Several monuments, such as Ghami's Mani wall (305 m long), Khorok Chorten, Ghami, Dakmar and Ghar Gonpa of Lo Gekar in Upper Mustang, have kept the legendary history of Padmasambhav alive.

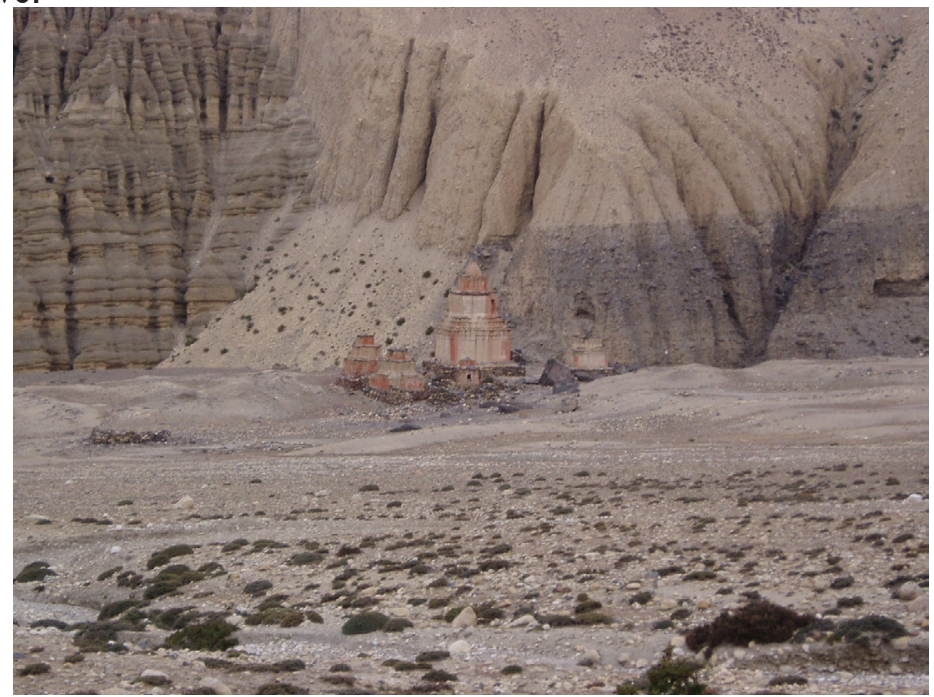

Photo 2: Khorok Chorten, Ghami

Ghar Gonpa of Lo Gekar is believed to be a monastery built at the same time as Samye Gonpa in Tibet, namely in the $8^{\text {th }}$ century. Likewise, the famous Indian teacher Atiśa visited Lo en route to Tibet in the $10^{\text {th }}$ century. Lower Lo was called Serib until $13^{\text {th }}$ century $\mathrm{AD}$ and the area above Kagbeni to Choser was called Lo tsho dun (Upper Mustang).

The first king of Lo-manthang was Amadpal, who was born in $1387 \mathrm{AD}$. He built the wall around the settlement of Lo in the second half of the $15^{\text {th }}$ century. He also built the four-storey palace in 1440 AD. Mustang was under the influence of Jumla in the $16^{\text {th }}$ and $18^{\text {th }}$ centuries. When Jumla was annexed to Nepal in 1789 AD, Mustang became an integral part of the country along with it. But its king was recognized as a local king. The past king, Jigme Palbar Bista, was believed to be the $24^{\text {th }}$ descendant of King Amadpal.

There are many accounts on Lo Mustang written by 


\section{Prakash Darnal}

researchers, travelers and writers like Da Gargnano Guiseppe Maria (1759), Kirkpatrick,W. J. (1811), Hamilton, B. F.(1819), Hodgson, B.(1819), Smith, C.T.(1852), Montgomerie, Lt.Col. T.G. (1875), Oldfield, H. A. (1880,1882), Hedin, S (1909, 1916-1922), Ekai Kawaguchi (1909), Guiseppe Tucci (1950), David Snellgrove (1961), Michel Peissel (1969,1975), Harka Gurung (1980) David P. Jackson (1976-77), Tiwari, D.N. (1985), Prayag R. Sharma and Jagman Gurung (2000) and Ramesh K. Dhungel (2002).

Their important writings were valuable information to know about the Lo Mustang. The first writer to mention about the Lo Mustang was Da Gargnano Guiseppe Maria (1759). Tucci has written "Journey to Mustang" (1952) Probably the first westerner to research history of west Nepal correlating with Tibet. David Snellgrove has mainly focused on Tibetan Buddhism. Michel Peissel (1964) was the first person who tried to collect history of Lo Mustang from Molla. But it was David P. Jackson who analyzed "Molla" and was able to write "the Mollas of Mustang". The credit goes to D.N. Tiwari's article "Cave Burials from Western Nepal, Mustang" which was initiated to explore and excavation in Southern Mustang. "Blo Mustang Ko Sanskritik Sampada" written by P.R. Sharma and Jagman Gurung fulfilled the lacuna about the cultural heritage of Lo Mustang. Ramesh K. Dhungel's "The Kingdom of Lo (Mustang) a historical study is a political history of Lo which narrates the history from the beginning to the present with sources found from both Nepali and Tibetan historical documents. It has elucidated the unique culture of Tibetan Buddhism tradition as well as political history of Lo Mustang.

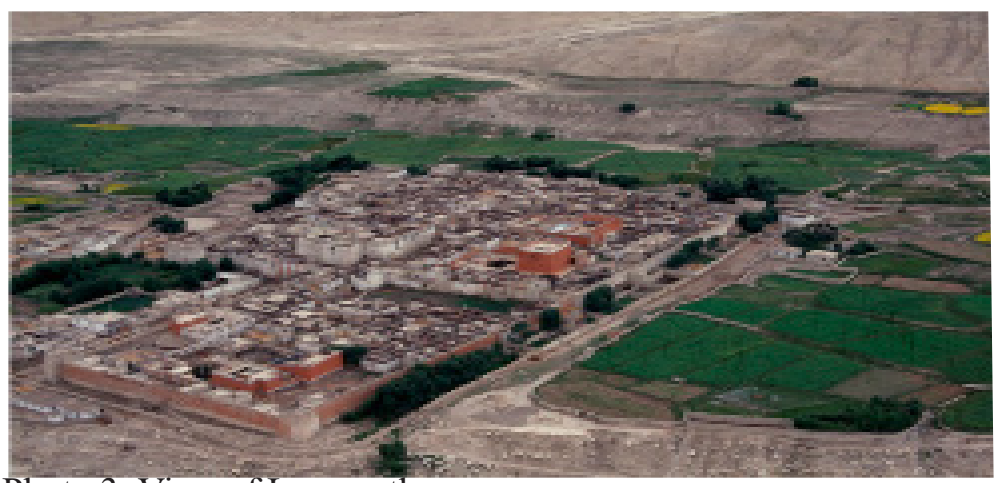

Photo 3: View of Lo-manthang 
Jhyampa Monastery is the oldest monastery inside the walled settlement. Built by Amgon Bzangpo in 1447 AD, it was restored by Bsam grub dpal bar in $1663 \mathrm{AD}$. It is $42 \mathrm{~m}$ long, $24 \mathrm{~m}$ wide and $16 \mathrm{~m}$ high. The main entrance is in the east. Its courtyard has an open gallery supported by wooden pillars. The metha ('wooden capitals') above the pillars are beautifully carved in Ranjana script. Most of them, though, are cracked and out of plumb. Nor are the rafters and joists of the gallery in good condition. It is a three-storey monastery made of clay, stone and wood. There is a circumambulatory path around the sanctum. The walls bordering the path contain paintings. Owing to water seepage through the walls, however, most of the paintings are now damaged, especially on the western and northern walls. The rafters and joists are broken along the western and southern parts of the path. There are cracks in the northern wall. The doorframe of the sanctum has a carved Chepū above it. The sanctum itself features ten wooden pillars set on attractive earthen pedestals inscribed with Ranjana script. The huge figure of Jhyampa (Maitreya, the future Buddha) in the second storey is strikingly beautiful. There are sculptures, too, of Dorje Semba and the Buddha, along with three wooden chörtens. The interior walls of the second and third storeys contain more than 100 painted mandalas. It is not an exaggeration to say that this monastery is a treasury of wall paintings. But the seepage of rain and snowmelt has damaged these marvelous mandalas as well as the monastery itself. Repair work on the third roof started this year 2001 AD, which can only be welcomed. We learned that the rafters and joists of the first storey on the east and north and some of the parts of the top roof were repaired fifteen years ago.

The cantilever roof on the east side of the second storey was also restored. The broad and awkward skylight has now been given a better shape, one much more practicable than the previous one of the third roof. The restoration work of monastery have been completed but the conservation work of wall painting is still continuing.

\section{Thubchen Monastery}

The second most important monastery in the walled settlement of Lo-manthang is Thubchen. Constructed in stone, clay and wood. It is $37.20 \mathrm{~m}$ long, $24 \mathrm{~m}$ wide and $12 \mathrm{~m}$ high. The door of the main 


\section{Prakash Darnal}

entrance, facing east, is beautifully carved, with the upper part of the door frame containing Ranjana script, and above it is a row of six lion heads. Inside the main entrance there are huge earthen statues of Dhvajarāja (Vaiśrāvaṇa) and Vīṇārāja (Dhṛtarāṣțra) to the north and Khadgarāja (Virūụhaka) and Caityarāja (Virūpakșa) to the south. There is another carved door leading into the sanctum. The main pillared hall is astonishingly large. There are only 35 pillars now, but evidence shows that there were originally 42 pillars. The northern wall was at some point shifted inward, which required the loss of seven pillars. The central ceiling is raised high towards a skylight, which is bounded by a square of 36 lion heads in the projecting joists. According to one available document, the northern wall was rebuilt in 1815 by Padma Bhuti.

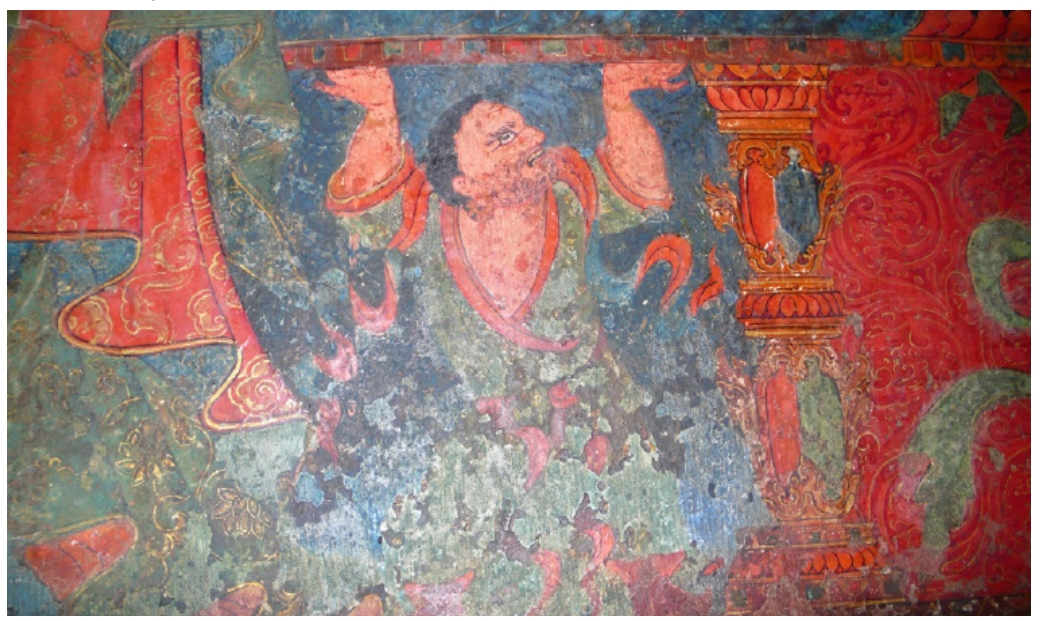

Photo 4: Wall painting of Thubchen monastry

It was noticeable that the wall had been plastered first with fine yellow mud containing bits of sand or grit, and then grey earth mixed with cow-dung, grass and the like was applied in a second layer. Finally another fine layer of earth was introduced as the base for the original painting. The plaster layer was found to be $4 \mathrm{~cm}$ thick, but the later painted wall proved to be devoid of the grit layer. The eastern wall of the sanctum has six large images featuring the peaceful postures of the Buddha, with a thousand small Buddhas around him and the Vairocana Buddha in the gesture of the mudra of setting the dharmacakrain motion in the middle of the row. Among 
the images, two bear captions in Tibetan script. There are eight paintings of the Buddha on the southern wall and one on the western wall, behind the Namgyal Chörten. Two figures in the act of lifting the Buddha in asana are quite interesting, showing as they do the influence of Chinese art. These paintings are original and, according to a molla, date back to the $15^{\text {th }}$ century. The paintings on the (rebuilt) northern wall, though, only go back to the $19^{\text {th }}$ century. One of the $19^{\text {th }}$ century paintings of Mahākāla was detached while repair work was being done on the wall at the western side of the northern corner. The (undismantled) northern wall (5.40 m long), however, has still two original wall paintings. Each painting is $7 \mathrm{~m}$ high and $3.40 \mathrm{~m}$ wide. These are artistically beautiful secco paintings whose pigments consist of the minerals powdered malachite, azurite and gold. Most of the wall paintings have suffered damage from dampness and cracking. A swath of the lower portion of the paintings some $1.40 \mathrm{~m}$ in width was destroyed when a defective part of the wall above the paintings was carelessly restored. But now these wall paintings have been subjected to chemical treatment (cleaning, consolidating and conserving). Dr. Rodolfo Lujan and his team (including trainees) have been achieving wonderful results in their work. (Darnal, 2000 pp 30-32)

On an earthen platform at the western sanctum are figures of Namgyal Chörten, Khadchheri Lokeśvara, Thubchen (Śākyamuni Buddha), Mañjuśrī and Padmasambhava with his two consorts. In front of these sculptures are Vajradhara, Padmasambhava with his two consorts, Aparamitra and Hayagrivva. All these sculptures except for the copper Thubchen were fashioned in clay.

This marvelous monastery was long in a state of dilapidation. The planks and joists above the images seemed on the point of collapse. Some of the pillars and beams were also out of plumb.

The main cause of damage was water penetration from the walls and roof. The restoration work, which has been going on since 1998, is as follows:

- The whole roof structure was completely repaired. The deteriorating or damaged rafters and joists of the roof were replaced and covered over again with stone and mud. The parapet around the roof was covered with a layer of stone.

- The sky light in the roof was modified. Before, light entered only 


\section{Prakash Darnal}

through the upper section, but now light enters also from the south. The roof of the vestibule was repaired.

- The main entrance including the six lions was also renovated.

- The wall featuring Khadgarāja and Caityarāja was subjected to conservation measures.

- There are wall paintings in this room too.

- The staircase abutting on the north wall was strengthened, and a hole was made in the north-east corner of the roof in order to admit more light.

- The area to the south of the entrance, which used to be empty, is now to have a two-storey structure built on it for housing the wall paintings.

- The kitchen beside the entrance, once an eyesore that diminished the grandeur of the gonpa, was demolished.

The King Mahendra Trust for Nature Conservation (Annapurna Conservation Area Project) and the American Himalayan Foundation have been working together under the Thubchen Gonpa Conservation Project to conserve this significant monument. It is indeed a matter of great pleasure that all conservation work on the Thubchen Gonpa (except for the chemical treatment of the wall paintings) has been completed according to the norms of archaeological conservation. But the local people are interested to fill missing part of original wall paintings which has been criticized by art historian.

\section{Lomanthang Palace}

The palace was constructed in mud, stone and wood, and counts nine corners. It boasts of both wall paintings and Ranjana inscriptions. The main entrance to the palace is in the east. It has been coated with a white layer of lime. The palace has a valuable collection of texts, including the Kanjur, Tenjur, Așțasāhasrikā-Prajñāpāramitā and Śatasāhasrikā-Prajñāpāramitā. It is four storeys. But now the palace is in worse condition. It needs urgent restoration. 


\section{Choedye Monastery}

Choedye monastery was built by Tashi Goyen in the $15^{\text {th }}$ century. The monastery continues to house practising monks. Valuable sculptures, books, thangkas and masks belonging to the Jhyampa and Thubchen monasteries are kept there for security. The famous traditional Tiji festival is conducted every year by the monks there.

\section{Lomanthang Wall}

The wall around Lo-manthang was built by A ma dpal, the first king of Lomanthang, in $1440 \mathrm{AD}$. It is $1.5 \mathrm{~m}$ thick at the base. The base consists of large uncut and unmortared stones. Over this base lie blocks of gyang (beaten clay, $40 \mathrm{~cm}$ wide, $50 \mathrm{~cm}$ high and $3 \mathrm{~m}$ long) tapered at the top. Pop bricks (of clay, $42 \mathrm{~cm}$ by $13 \mathrm{~cm}$ by 21 $\mathrm{cm})$ were introduced during later repair work. The height of the wall is $8.55 \mathrm{~m}$. Parallel to the wall is a stone walkway (60-70 cm wide) situated $75-80 \mathrm{~cm}$ below the top of the wall, allowing one to along the wall through around the town. The wall surrounding Lo-manthang has five corners, each accompanied by several bastions (zhong). The average height of a bastion is $10 \mathrm{~m}$. The wall runs $270 \mathrm{~m}$ along the west side and $153 \mathrm{~m}$ along the south. It is $59 \mathrm{~m}$ shorter in the north than in the south, and encloses 3.51 hectares (68.87 ropanis). The main entrance through the wall lies in the north. It is $3 \mathrm{~m}$ wide and 5 $\mathrm{m}$ high. It is the only sizeable entrance into the fortress, even though now many additional openings in the wall have opened up.

\section{The Importance of the Wall}

Lo-manthang is the only walled city in Nepal. Its first ruler built the wall around his palace with the idea from the beginning that it would turn the city into a fortress and so protect its inhabitants. Currently 175 residences and 1,009 inhabitants are recorded as living within the city. The most significant monuments inside the wall are three red monasteries, the white palace, twelve chörtens and a mani wall. There are altogether 60 spouts and 25 openings in the wall. These spouts are used for roof drainage, which is the main reason for the deteriorating condition of the wall. The lack of proper drainage 


\section{Prakash Darnal}

inside the wall would thus seem to pose a serious problem. Last year the eastern wall of Choedye Gonpa collapsed completely and is now being restored year by the Annapurna Conservation Area Project (ACAP). Surendra Bista pulled down the dilapidated portion of the wall, which, had it been in effect at the time, would have been against provisions of the latest Ancient Monument Preservation Act of 2013. Later he reconstructed it with pop bricks, which are unsuitable to structures made of gyang. Another part of the wall near the dismantled portion collapsed on its own owing to its poor state. The Department of Archaeology contributed Rs. 1,216,756.09 from $1987 / 88$ AD to $1989 / 90 \mathrm{AD}$ for the maintenance of the wall (Darnal 2001; pp. 30-38).

\section{Lo Ghekar}

It is the most important monastery of Lo tsho dun because it is the only common monastery and Nyingmapa sect of Lo tsho dun. Amapal built the palace of Tsarang and monastery near the Lo Ghekar because it was subdueded by padmasambhav over Dakini(demon). It was renovated by King Don grub r-dorje (1580-1594 AD). The monastery has Chortens in its four corners. Beside it there are believed to be 108 Chortens, some have been already renovated. The main entrance has paintings of Chaturmaharaja. There is two part of Dukhang the inner is older one and the outer is later. Carving on slates images are kept in outer Dukhang. The upper storey has sculpture of Padmasambhav, Lama and Mahankal. The room called Mani Lhakhang has Mani-Padma Lokeshwor which was donated by queen Nyizla in $17^{\text {th }}$ century AD. In 2038 BS also it was repaired and it is under restoration jointly carried out by King Mehendra Trust for Nature Conservation and American Himalaya Foundation.

\section{Charang Palace}

This palace was built by A ham Don grub rdorje during his rein in 1580-1594 AD. But the evidences show that the palace was already existed. King Dun grub rdorje might have extended or rebuilt it. The palace is five storey constructed by mud, stone, and wood. It is a grand structure standing still with past glorious history. The palace 
has main entrance on the South. A stone near it said to be from Jumla, is interesting. The first storey has toilet, rooms and Chorten. The second storey has weapons, sculptures of Maitreya, Tara, Chorten (gold plated), Lokeshwor, (wooden), copper Astadal, box, Astasahsrika pragyaparmita with gold letter and carving wooden cover, a human hand and six sculpture made of clay. The third and fourth have rooms only. The Eastern parts of the palace has been turned into ruin now.

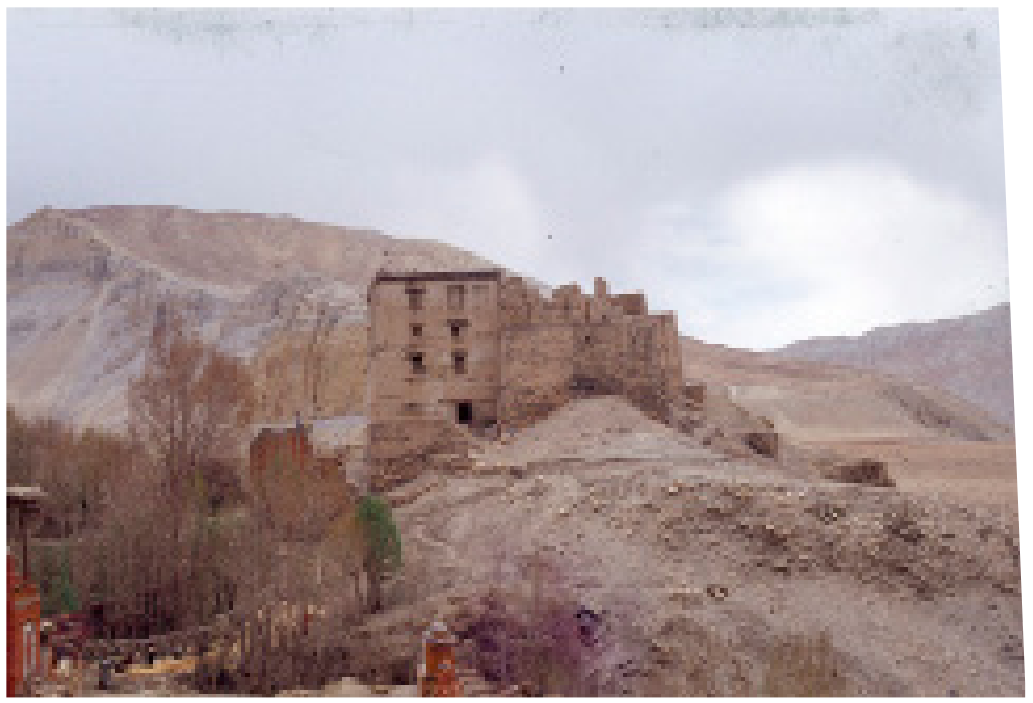

Photo 5: Charang Palace

\section{Charang Monastery}

The first independent king, Amapal, built his palace at Lo-manthang but he sponsored the founding of the new Thub-bstanbshad-grub dar - rgyasgling monastery in Lo's old headquarters, Charang, which has remained Lo's most active religious and education center from the time of its independence to the present( Dhungel,2002 p. 86). The present monastery was built by bsum grub rdorje in the $16^{\text {th }}$ century AD. It is three storey constructed by mud,stone, and wood.

There is Ani Gumba which is abandoned and deserted but its painting seems oldest in the Charang. It also needs urgent restoration and conservation. 


\section{Prakash Darnal}

\section{Cave Archaeology in Mustang}

Department of Archaeology had signed with Coulfield Meisezahl Institute (Bonn) in 1991 for scientific study and archaeological excavation. The investigation and excavation was conducted in collaboration with the institute of Prehistory, University of Cologne, Germany. Investigations and excavations conducted under a joint Nepalese-German archaeological research project for prehistoric remains in the caves of Chokhopani (Tukuche), and at Phudzeling, Mebrak, Khinga, Dzarkot and Garabdzong in Muktinath (Lower Mustang) from 1992 to 1997 AD also yielded important evidence, Child Mummy from Mebrak suggesting that the Kaligandaki valley has been inhabited for nearly three millennia and that there were links with the Indian subcontinent as well as with Tibet and Central Asia. Artifacts collected from the burial sites of Chokhopani include carnelian beads, shells, faience, copper bangles, copper anthropomorphic figures, bodkins (stone needles), channeled spouted bowls, cord-decorated pottery and storage jars, now on display in the Kapilvastu Museum. A child mummy ( $4^{\text {th }}$ century BC) excavated from a cave in Mebrak is now in the National Archives, but will soon be put on display in the National Museum.

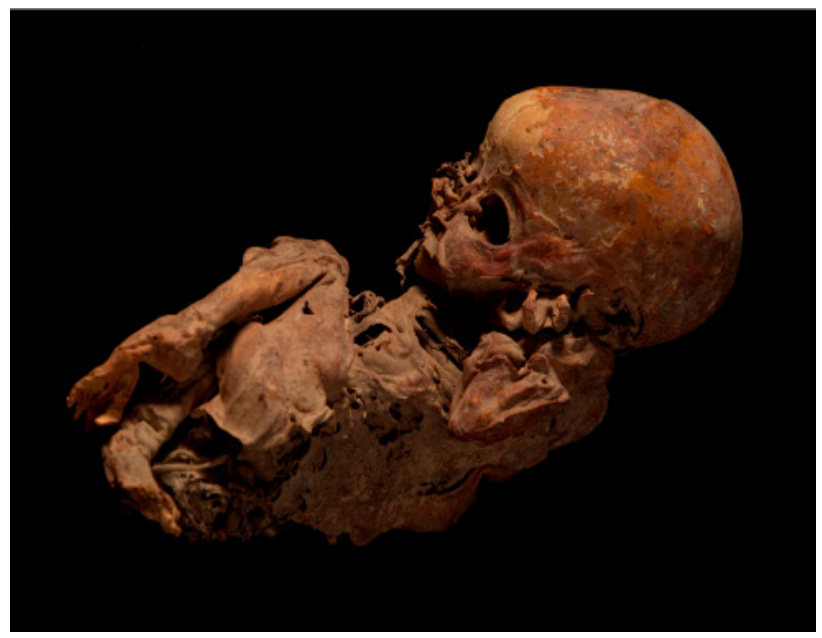

Photo 6: Mummy from Mebrak 
Dhaulagiri Journal of Sociology and Anthropology Vol.11, 2017|13

\section{Rock engravings}

Petroglyphs studied in Kak-nyingba, Samar and Te support the evidence of the Neolithic period remains. Likewise, a cave study in Lower Mustang by the Department of Archaeology and the University of Cologne found pieces of evidence dating back to the $8^{\text {th }}$ century B.C.

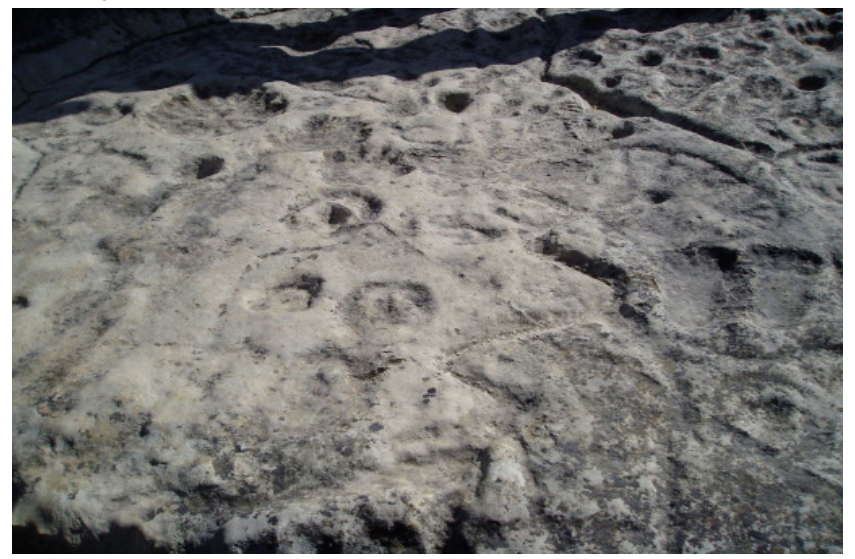

Photo 7: Rock engrave of Samar

In 2007, the Upper Mustang project conducted reconnaissance of additional caves-GoijePhu, Samzhung, ZhongKuyore, Rinziling, and Nhyeyul, among others - that, despite their location more than 150 feet above the ground, were carved and expanded in the Late Holocene, around $1000 \mathrm{BCE}$. This date for the earliest occupation of the caves is based on groundstone tools found near Kagbeni, which resemble "Neolithic" tools like those described above. Survey of these caves revealed that they contain thousands of pages of Buddhist text and invaluable wall paintings from the $14-15^{\text {th }}$ centuries, habitation deposits, and burials dating from the earliest occupation circa $1000 \mathrm{BCE}$ to the Early Historic era, from 200700 CE. An analysis of Samzhung cave burials revealed elaborate mortuary treatment: preparation for sky burial similar to the practices found in the region today; gold masks and beads adorning the human skeletons; copper pots and other artefacts placed alongside the dead (Eng and Aldenderfer, 2011; pp 9-32) and the third phase project has been signed for 2016 to 2021AD. 


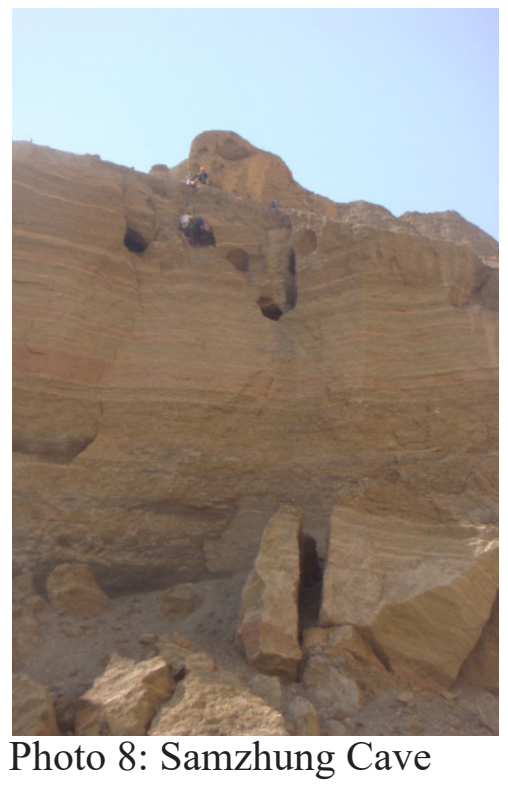

\section{Mandala Cave}

The Mandala cave is located in Choser VDC ward no 2. It is on the same hillside as Nyiphu monastery, about half an hour further north. There are four ruined chörtens in front of it. The upper of its two storeys features16 mandalas on its ceiling. The largest is 7'3" in diameter. Figural paintings on the northern, eastern and western walls have already become hard to identify. There is a section of the ceiling next to the mandalas which has Tibetan script, while the southern wall displays a painting of the Buddha.

\section{Phodaling Cave (GoijePhu)}

The Phodaling cave is located in GoijeTha village (ward 8, Choser VDC), some three and a half hours on horseback from Lomanthang. This cave has around 70 paintings including a panel of 56 arranged in three rows. The paintings depict palm trees, monkeys and women reminiscent of the Ajanta Caves in India. Some, like the one that has been titled Ejaculation, portraying a private organ, are rather unusual;others, such as the music instruments, are more conventionally interesting. The cave contains one of Nepal's most 
Dhaulagiri Journal of Sociology and Anthropology Vol.11, 2017|15 important finds of murals, and definitely the oldest of its kind in Upper Mustang. Tibetan inscriptions underneath each member of the panel describe their content.

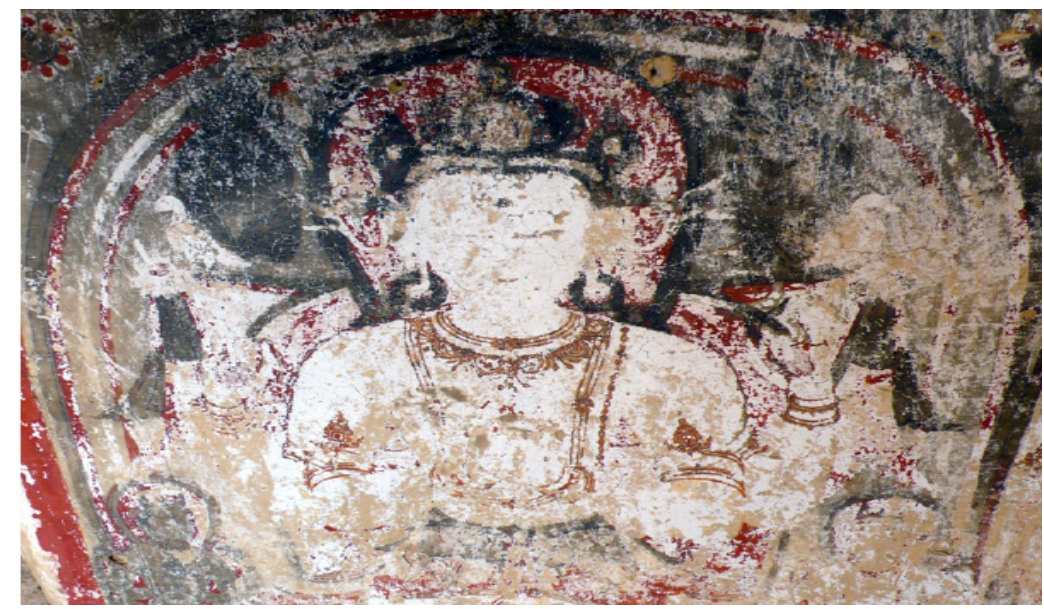

Photo 9: Painting of Potaling Cave (Goije Phu)

\section{Chukumau Dhakpu Cave}

The Chukumau Dhakpucave is located in Chu Kumārapo village (ward 3, Choser VDC) on theway to the Phodaling cave, to the right of the trail along the course of the Samjung. It is a three-storeys cave. Several manuscript folios, including ones with letters written in gold, were found scattered in a corner of cave. A stone with Tibetan script and a mud-and-cloth head of the Buddha were also found.

\section{Shaka Phu Cave}

The Shaka Phu cave is located across the Nyanol River from Nyanol village (ward 8, Choser VDC). Since our visit the cave has become inaccessible. There is a kabung in the southern part of the cave, but it has been severely damaged from pinnacle to socle. Its length and breadth at the base is 6'4", and its height is $8^{\prime} 2^{\prime \prime}$. The western side of the socle bears a flag. Likewise, a Kubera, fish and conch adorn the northern side, and an endless knot and wheel the eastern side. The cave's eastern wall has paintings of the Buddha, a monk and Vajrasattva. 


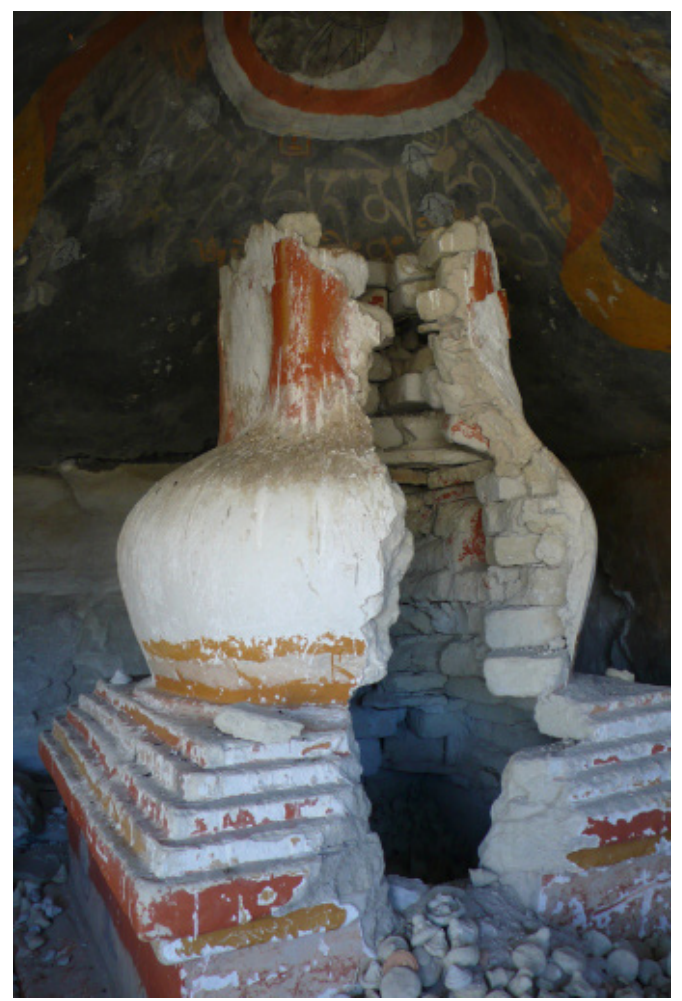

Photo 10: Kabung of Shaka Phu

\section{Marchung Cave}

There is a hot spring about 30 minutes on foot from Lo-manthang. The Marchung cave is situated between it and the Samjung River, near the left bank of the river. The lowest part of it is used as an enclosure for sheep. The upper part above it is inaccessible. The cave is in four storeys. It has an interesting Yamāntaka and five Vajrayoginīs wall paintings. In addition, liner sketches of four figures, a diagnostic rim potsherd and numerous folios containing Tibetan script have been discovered in this cave. 
Dhaulagiri Journal of Sociology and Anthropology Vol.11, 2017|17

\section{Tashe kabung}

When riding from Yara village to Luri through a stream on horseback, we came after half an hour upon a ruined chörten visible on the side of a cliff. Above this chörten there was a cave, but it was inaccessible. Mary Slusser and Lila Bishop (February, 1999) have published an article on this site: "Another Luri: ANewly Discovered Cave Chorten in Mustang, Nepal" in Orientations. The chörten is severely damaged on its eastern side from pinnacle to dome. It has an octagonal socle displaying the eight auspicious symbols and the Four Guardian Deities of the cardinal directions. The western wall of the cave bears a painting of Khadcheri and a monk. The dome is also adorned with the eight auspicious symbols. Folios representing five different types of script lay scattered about in the north-east corner. A fragment rim of potsherd made of mud and paper was also found.

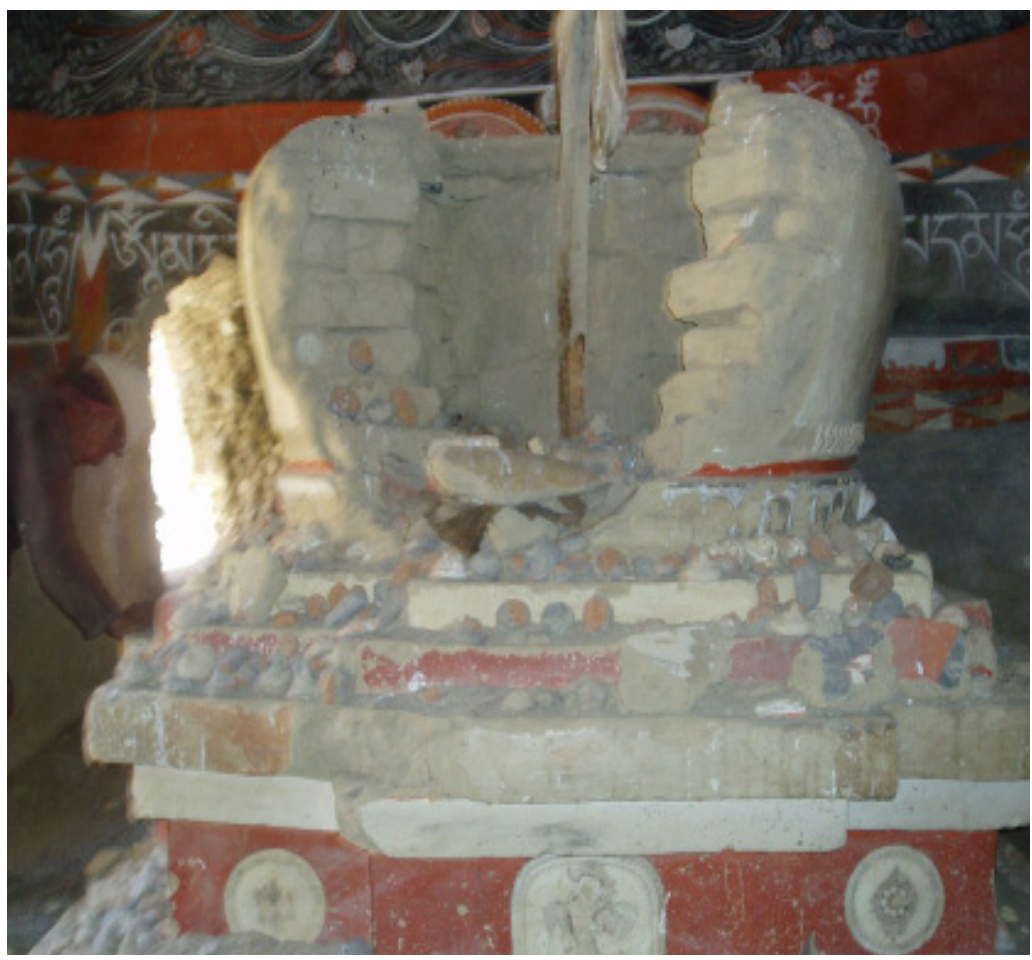

Photo 11: Tashe Kabung 


\section{Prakash Darnal}

\section{Luri Cave}

The Luri cave is just half an hour's walk beyond the Tashe kabung (cave chörten). Located in Ghara village (ward 6, Surkhang VDC), it contains the only accessible cave chörten in Upper Mustang, Luri monastery is currently in a state of ruin. There are five chörtens and mane walls along the ascent to it. It is built above the hill cave. The trail up is narrow, and a wooden bridge spans a crevasse of mud, grit and stones. The main entrance has a wooden door. The cave is in four storeys.

The chörten has longbeen renowned for its intact and beautiful paintings dating from the $13-14^{\text {th }}$ century AD. Its socle exhibits the eight auspicious symbols along with Four Guardian Deities. The dome contains paintings of Namgyal, Khadcheri, Vajrasattva and Lokeśvara on its eastern, western, northern and southern sides respectively. The west wall of the cave offers images of Lama, the Buddha (with Śāriputra and Maudgalāyana), Vajradhara, Vajrasatva and Khaḍgayoginī. Likewise, beautiful paintings of eight siddhas and a mandala look down from the cave ceiling upon the chörten.

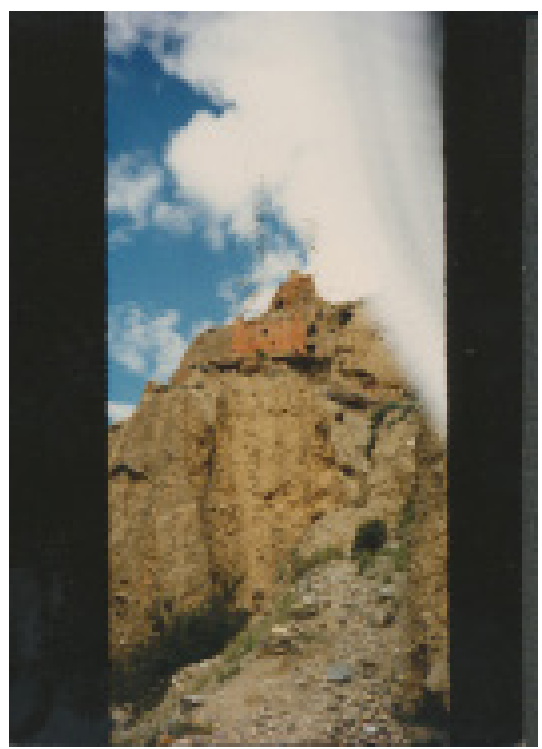

Photo 12: Luri cave 


\section{Tangya kabung}

Tangya village comprises wards 7/8 of Surkhang VDC. It is famous for a group of chörtens and numerous caves. A kabung was discovered by us in a cliff some 15 minutes away from the village. It is well preserved and indeed wholly intact. No paintings were found in the cave, only the chörten, which has a Ranjana inscription on it.

\section{Charang Cave}

Charang is an important historical and religious site second only to Lo-manthang. Its palace, monastery and chörtens are very significant. There are caves to the north and east of the village. The latter cave has altogether 33 chambers. No artefacts were found; only a few swastikas painted on the wall of the cave.

\section{Dhakmar Cave}

The colour of the cliff at the famous Dhakmar ('Red Blood') cave, it is believed, is due to its being a site the blood of a demoness was shed at in a confrontation with Padmasambhava. The cave is located in Ghami VDC, near a house belonging to the king of Mustang. There are no inscriptions or paintings in its chambers. A sample of wood found in the cave was collected for dendrochronological study.

\section{Chili Phu}

The Ghami caves, also known as Chili Phu, can be seen across the Ghami River from all the rooftops in Ghami. These very interesting eight-storey caves contain many chambers. Rope impressions and sketches of a monastery have been found in them.

\section{Tama Gaon Cave}

The Tama Gaon cave is west of Tama Gaon (Ghiling village) on the other side of a small stream. The entrance to it can be identified by a stone plinth in front of and red pigment around the opening. The cave itself has many levels and contains a sketch of a chörten and Ranjana inscriptions. 


\section{Prakash Darnal}

\section{Kabung Nar Gonpa Kang}

Gonpa Kang monastery, located on the right bank of the Kali Gandaki River in ward no. 3 of Chuksang VDC, is one of the region's most important monasteries. A kabung thirty minutes on foot from the monastery was found to be in a ruined condition. Its base is $8^{\prime} 8^{\prime \prime}$ in diameter, and its height 9'6". The most interesting finds were five paintings, four of which are of female deities (Darnal, 2008; pp 1-31)

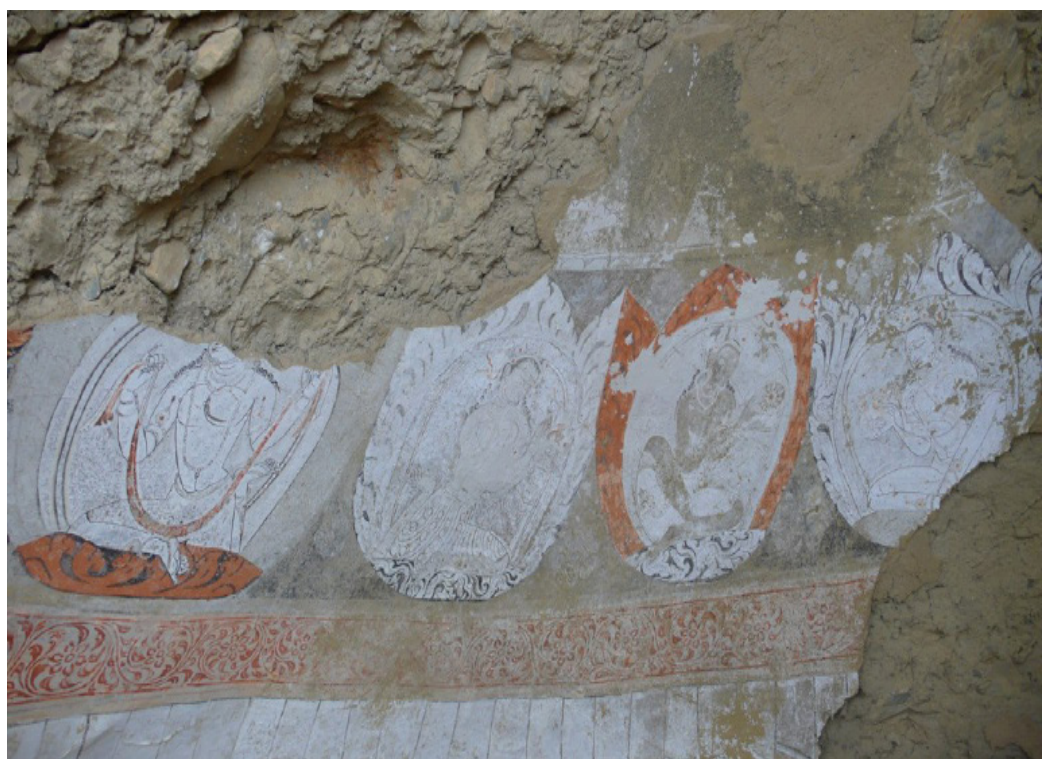

Photo 13: Painting of cave near Gonpa Kang

\section{Impact of Road on Cultural Heritages in Upper Lo Mustang}

Last year 2007, we had seen Lung Kurki (the left bank of the Kaligandaki) filled with mud, dust and stone during the road construction. Although the construction work is complete; the scenario has not changed this year. The Kangni Chorten and group of chortens at Charang are in vulnerable condition due to road. Though Sumda chorten has been done restoration. It is still in risk due to surrounding road. The vehicles have already damaged the chortens in front of the Lo-manthang's main entrance. There is no doubt that the loaded trucks' vibrations will affect not only the chortens but also 
the fort wall of Lo-manthang. Most of the heritages of Lo Mustang are composed of mud and stone. These century old heritages are in disintegrated and degenerated conditions now. Further vehicular movement and the vibration caused by it may cause irreplaceable lost to heritages. At one hand, we cannot deny the importance of road, cannot think of the place, which is not touched by it. On the other hand, we cannot sacrifice or let destroy the culture for the mere sake of road. Road symbolizes an infrastructure of development of economy, tourism and upliftment of people life. However we should be aware of minimizing the adverse effect it induced to the cultural heritages which has taken hundreds of years to take the shape like we see today. For this purpose, road should be constructed in a planned way not haphazardly as done at present. Many cemented new structures have been constructing which will destroy the soul of heritages.

\section{Heritage Conservation}

According to Ancient Monument Preservation Act 2013 B.S. any monument more than hundred year comes into purview of Department of Archaeology. Therefore, heritages of Upper Lomanthang should be conserve according to the norms of archaeology. Scientific inventory of each and every heritage is important. The expert team consisting of an archaeologist, an architecture and a photographer need to investigate thoroughly for preparing conservation note. The practice of conservation of a heritage is, it must be restored by same traditional materials, size and shape as it was for its aesthetic and historical value. Final report with photos of before, during and after conservation becomes important document for posterity.

\section{Conclusion}

Heritages of Lomanthang are indeed unique for its geography as well as cultural aspects. Numerous chortens, caves, mani wall, monasteries are awaiting for planned restoration, for example Luri cave, Monastery of Samduling, Ani Gonpa and Chortens of Charang, Lomanthang and Lung Kurki on the way to Kagbeni. Lomanthang is the only one walled city of Nepal .There were only two houses in 


\section{Prakash Darnal}

1995AD, but increased eight times in 2004 AD. and still increasing which has diminished attraction of fortress wall. Mitigation measures are as follows:

1. Lomanthang should be thoroughly documented (detailed survey, drawings, mapping and inventory) and a master plan for its conservation should be prepared.

2. In order to stop the further encroachment and construction of buildings around the wall and to preserve the aesthetic and cultural value of Lomanthang, Government of Nepal should take immediate steps to declare the wall a protected monument under Clause 3 of the Ancient Monument Preservation Act of VS 2013.

3. Lomanthang is unique in virtue of its architecture, art, history, culture, religion, archaeology and festivals. It is the only intact medieval fort located in Nepal. It can thus be classified as a monument of international importance. Department of Archaeology is trying to propose it to enlist in the world heritage site.

\section{References}

DieterSchuh, Introduction.(1992). AncientNepal, nos. 130-133(JuneJanuary 1992-93), Department of Archaeology,Kathmandu

Darnal, P. (2000). "Lomanthanga sthita Gumbaharūko Bhittechitra: ek Carca." Rolamba, vol. 20, No. 3 \& 4, pp 30-32.

Darnal, P. (2001). The Cultural, Religious and Archaeological Heritage of Lomanthang and its Restoration, Ancient Nepal, No.148 pp .30-38. Department of Archaeology, Kathmandu.

Darnal, P. (2008). Reconnaissance of Caves in Upper Lo Mustang, page no .1/31, Department of Archaeology, Kathmandu

Dhungel, R. K,. (2002). The Kingdom of Lo (Mustang): A Historical Study. Kathmandu: TashiGephel Foundation.

Eng J, Aldenderfer M. (2011). Bioarchaeological analysis of human remains from Mustang 2010. Ancient Nepal 178 pp 9-32 
Darnal, Prakash (Orcid: 0000-0002-0927-1574) is archaeologist, former chief of National Museum, Chauni of Nepal. His research focuses on field archaeology, art, monument and culture. He had carried out excavation at Khoksar (Saptari), Dhangadhi, Vidhyapatigadh (Siraha), Manimandap (Dhanusha), Devdaha, Bhawanipur(Rupandehi), Shreekot (Acham) and Surkhet (Katkuwa). He has published hundred of articles in Nepali and English in Journals of Nepalese Studies, Ancient Nepal, The Rising Nepal, The Kathmandu Post, Rolamba, Garima, Madhuparka, Gorkhapatra, Pragya etc. A book, "Hamro Sanskritik Dharoharharu" published in B.S. 2073. He has presented his paper in Annual Conference of H.N.B. Garwal University Srinagar in 1997, SAARC International Conference on Archaeology of Buddhism at Colombo in 2012 and $5^{\text {th }}$ International Congress of Society of South Asian Archaeology, 2014 in Raipur, India. He earned Master of Arts in History from Tribhuvan University, Kirtipur. He was under secretary in Nepal Government's civil service. He got Post Graduate Diploma in Archaeology from Institute of Archaeology (Archaeological Survey of India) New Delhi in 1996-98 AD. He has visited India, China, Srilanka and Germany.

Email: darnalp@gmail.com 